\title{
Exotics for the Lords and Gods: Lowland Maya Consumption of European Goods along a Spanish Colonial Frontier
}

\author{
Jaime J. Awe and Christophe Helmke
}

In the volume The Lowland Maya Postclassic, Arlen Chase and Prudence Rice $(1985,5)$ contend that Spanish presence in the Maya lowlands "is not clearly detectable in the archaeological record until the nineteenth century." To this they add that: "This is partially a consequence of an apparent reluctance on the part of the Maya to accept European trade items or at least to deposit them in the archaeological record." This point of view echoes the previous observation by Nancy Farris $(1984,110)$ that "Except for some simple metal tools [...] one can find little European material impact" on Maya culture during the early colonial period. Farris $(1984,45)$ also argued that the Maya of the Yucatan generally had a "cultural bias against European goods" and that the few tools and trinkets that were acquired "were passed on through generations as treasured heirlooms." Farris $(1984,45)$ further noted that, with the exception of metal tools and gunpowder, "which came to be regarded as a requirement for any fiesta, besides its use in hunting," there were only a few items that the Maya actually desired from the Spaniards.

While we would agree that the volume and diversity of European goods were limited along the lowland Maya colonial frontier, considerable ethnohistoric and archaeological evidence that has come to light in recent years, demonstrate both increasing acquisition and integration as well as desire, if not demand, for European objects by the contact period Maya. Avendaño y Loyola $(1987,29$; see also Means 1917, 131) went even further in his assessment of the Maya interest in obtaining Spanish goods, reporting that the Itza demonstrated an "insatiable desire" for these objects. Whereas all such assertions must be tempered by the relative ubiquity or scarcity of European objects in archaeological contexts, we can nevertheless identify a series of different driving factors that fueled the Maya desire for European goods. Among these was the acquisition of European goods as status symbols, for practical and mundane or quotidian purposes, as well as for their incorporation in ceremonies 
and ritual deposits to harness what Timothy Pugh $(2009,373)$ refers to as the "power of alterity."

Both the ethnohistoric sources and the archaeological record indicate that the Maya acquired European goods in different ways. A review of these sources suggests that these can be divided into major categories or headings. The two most common methods included: 1) gifts from the Spanish and 2) by means of trade or barter between indigenous peoples and Europeans, and down-the-line between indigenous groups (Blacker and Rosen 1962; Clendinnen 1987; Jones 1998, 503; Oland 2014, 2017, 127; Pugh 2009). Other methods of acquisition were as 3) payment for services, 4) tokens or rewards for conversion to Christianity, and as 5) "spoils of war" following violent confrontations between the two groups (Avendaño 1987; Awe and Helmke 2015, 347-348; Jones 1990, 188; López de Cogolludo 1688, bk. 11, Chap. 14, 648; Thompson 1972, 12). Below, we review the material evidence for each of these headings in turn.

\section{The Ethnohistoric Evidence: Acquisition of European Goods by Way of Gifts and Trade}

Despite its relative lack of detail, the ethnohistoric record actually provides a wealth of information regarding the presentation and exchange of European goods in the Maya lowlands. The first such example can be traced back to July of 1502 when, during his fourth voyage to America, Columbus encountered a group of Maya merchants near the island of Guanaja off the coast of Honduras (Chamberlain 1948, 9-12; Keen 1959) (Figure 11.1). Columbus' son later provided an eyewitness account of this meeting, plus an informative description of the seaworthy Maya canoes and the merchandise they were carrying (Columbus 1960, 231-232). He reported that when Columbus met the Maya merchants, "He greeted them with great kindness and presented them with some objects from Castille in exchange for some of the strange-looking things, to take with him in order to show what kind of a people he had discovered" (Hammond 1988, 221). $\mathrm{He}$ also noted that Columbus retained one of the elderly Maya merchants to serve him as a guide, that he renamed the old man Juan Pérez, and that on his release of the so-called Juan Pérez, Columbus bestowed upon him presents for his assistance.

The initial encounter between Columbus and Maya merchants was followed by three subsequent Spanish expeditions to the east coast of Mesoamerica from the island of Cuba, then known as Fernandina. The first of these expeditions was the 1517 voyage of Francisco Hernández de Córdoba. According to Bernal Díaz del Castillo $(1956,19)$, in preparation for the journey 


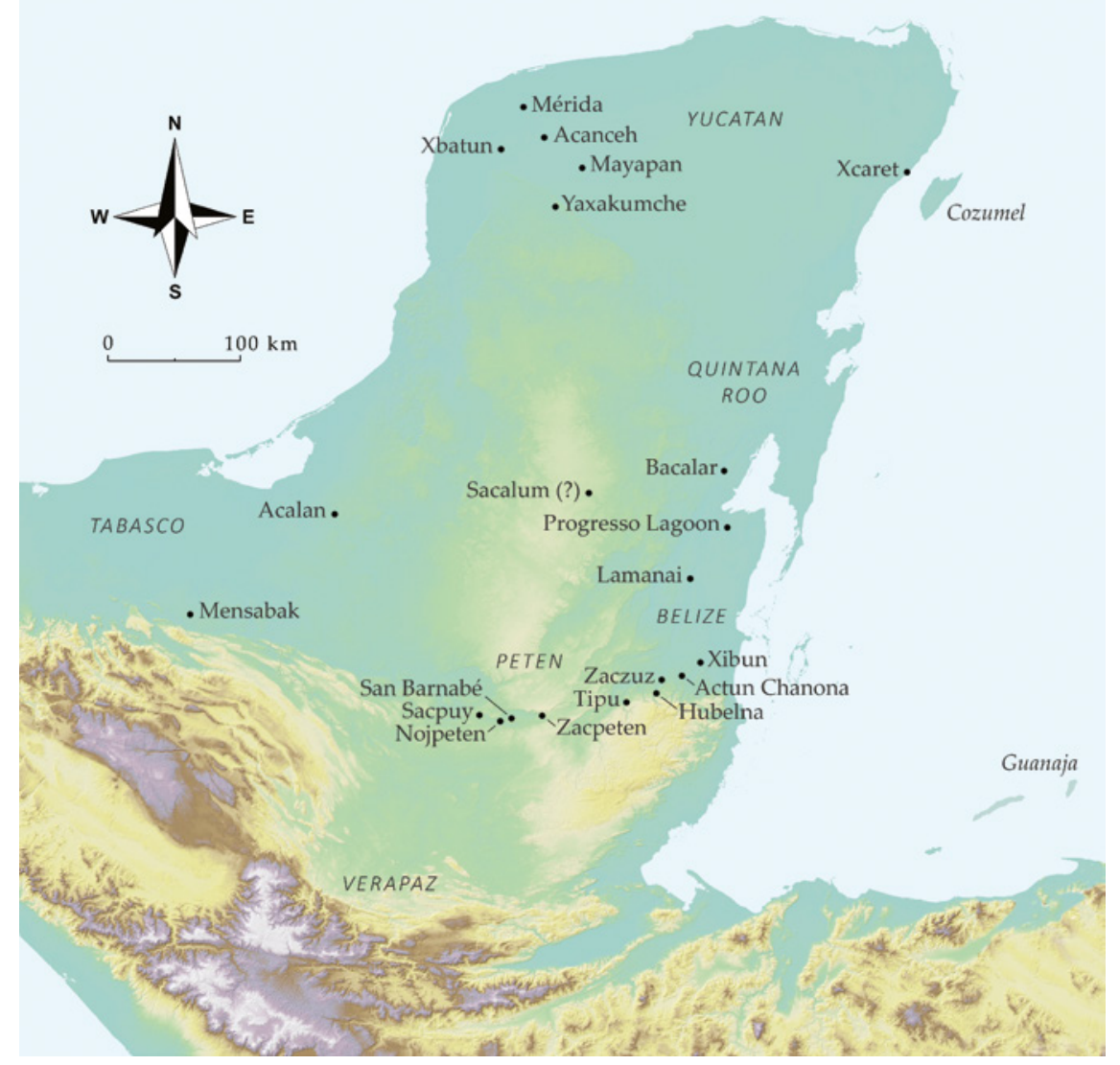

FIGURE 11.1 Map of the Maya area showing the locations of the most prominent settlements and localities mentioned in the text MAP BY CHRISTOPHE HELMKE

to the Yucatecan coast, Córdoba provisioned the boats with various supplies, and "bought trinkets to be used for barter." This practice followed one established early on by Columbus who extensively traded in glass beads and copper bells in the Bahamian Islands and the Greater Antilles during his initial voyages (Berman and Gnivecki this volume; Bedini 1992, 27; Keegan 1992, 183-205; Keehnen 2012). In the second expedition to the Maya coast from Cuba, this time under the command of Juan de Grijalva, Díaz del Castillo $(1956,29)$ notes that off the coast of Tabasco they showed the indigenous peoples who approached them in canoes "small mirrors and strings of green beads that they thought were of jadeite, on which they placed great value."

The third, and most consequential Spanish expedition, was that under the command of Hernán Cortés in 1519. For this trip, the Spaniards also provisioned 
their vessels with the various articles that were intended for trade (Díaz del Castillo 1956, 26). This customary practice is confirmed by the dispatches sent by Cortés to the Spanish Crown. In his first letter to Charles v, which was meant, in part, to curry favor with the Emperor at the expense of Diego Velásquez, governor of Cuba, Cortés noted that their little armada was provisioned with "boxes of laced shirts," beads and other merchandise (Blacker and Rosen 1962, 6). He also states that "We make special mention of this so that Your Majesties may know that the armada fitted out by Diego Velásquez was intended as much for trading merchandise as for privateering" (Blacker and Rosen 1962, 6). On his arrival at Cozumel, Cortés gave some beads, little bells and Spanish shirts to two native men and a woman who were asked to convey an invitation to meet with their chief and community (Díaz del Castillo 1962, 58). While at Cozumel, Cortés was informed of two Spaniards, Gerónimo de Aguilar and Gonzalo Guerrero, who, following their shipwreck and subsequent stranding on the coast of Quintana Roo, had been taken captive and were living in Maya communities along the coast. In an effort to secure their freedom, Cortés provided "all kinds of beads to ... two Indian merchants of Cozumel" who were to go and barter for their ransom on behalf of Cortés (Díaz del Castillo 1956, 41; 1962, 6o).

The ethnohistoric literature also mentions that following his landing along the coast of Veracruz, Cortés gave Aztec emissaries "a Florentine glass cup, much decorated and gilded, three Holland shirts, and other things" (Díaz del Castillo 1956, 59-6o; also see Díaz del Castillo 1962, 94). A few years later, while en route to Honduras in 1524-1525, Cortés (Blacker and Rosen 1962, 241-243) visited Nojpeten, capital of the Itza. During this first Spanish entrada to the Peten, Cortés gifted to the Itza the ajaw, or 'king,' Kan Ek', "a shirt, and a cap of black velvet, and some little things of iron, such as scissors and knives" (Means 1917, 34). When Cortés departed, he also left his injured horse with the Itza, a statue of which was said to eventually become an object of worship (e.g., Bennett 1998, 189-190).

Fray Agustín Cano's account of Díaz de Velasco's entrada from highland Guatemala to the Peten in 1695 noted that while traversing Mopan territory in what is now the southeastern Peten - an advance Spanish patrol encountered a group of Itza hunters. When the Itza drew their weapons, the Mopan guide asked that they "be peaceable and not fight, because those were merchants who sold axes and machetes" (Jones 1998, 135; Means 1917, 98). According to Means $(1917,98)$, the soldiers then exchanged "knives and many other little trifles" for blankets from the Indians. A few days later, Velasco's party captured a Maya by the banks of Lake Peten. When questioned, the prisoner replied: "That he had gone to look for merchants to buy axes and machetes" (Jones 1998, 138). Scholes and Roys $(1948,245)$ also report that Acalan merchants traded knives, axes and machetes, among other things, with the Maya of northern Yucatan. 

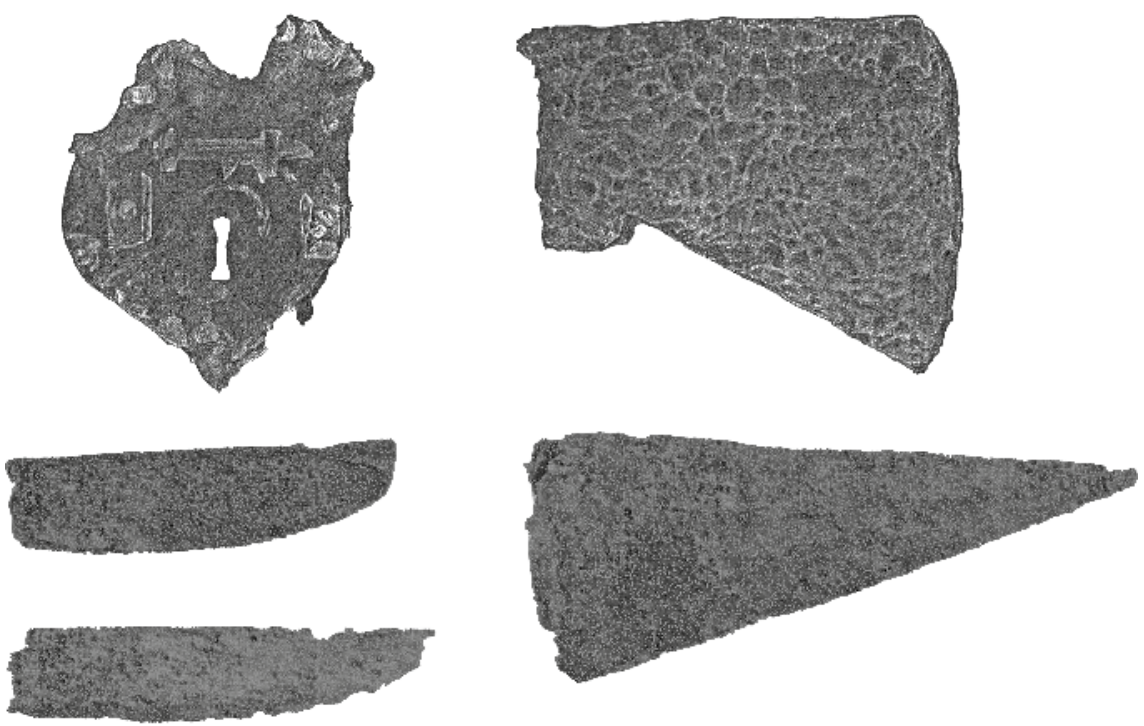

$5 \mathrm{~cm}$

FIGURE 11.2 A selection of metal objects found at Lamanai. To the left is a European lock plate, from refuse around the later church, above two knife blades. To the right is an axehead above a hatchet and a nail

DRAWINGS BY EMIL HUSTIU AND CHRISTOPHE HELMKE BASED ON

PHOTOS BY BRIAN BOYLE

During the conquest of the Itza, generals Martín de Ursúa y Arizmendi and Melchor de Mencos, and Alejandro Pacheco complained that the "metal tools and other barter items for the Itzas had still not arrived from Verapaz by March 18th" (Jones 1998, 364) (Figure 11.2). Being short on food, and eager to acquire maize for their small army, Ursúa y Arizmendi and Mencos sent a party to Sacpuy where they bartered machetes, knives, axes, silver coins and salt for maize (Jones 1998, 366).

\section{3}

\section{The Acquisition of European Goods to Encourage Conversion}

The ethnohistoric literature contains numerous references of gifts given by priests to encourage Maya conversion to Catholicism (Graham et al. 1989, 1258). For example, Villagutierre Soto-Mayor (1983, 16, also see Jones 1989, 265-266) provides a list of non-perishable European objects that were gifted to the Itza prior to their conquest. The items included axes, knives, machetes, glass beads, earrings and necklaces. Van Oss $(1986,16)$ reports that a common Spanish 
practice in highland Guatemala was the gifting of axes, blankets, hats, knives, needles, rings, scissors, and other goods to caciques following their acceptance of Christianity. Elizabeth Graham (2011) further notes that in addition to glass beads and needles, the Spanish friars often carried other gifts, including mirrors, religious paintings and "other paraphernalia" that were awarded to the Maya following their conversion to Catholicism (Figure 11.3b-c). Some of these "other paraphernalia" included rings, lace tags and objects made from jet and amber (Graham 2011, 234).

In Fray Andrés de Avendaño y Loyola's description of the entrada to Tipu and Lake Peten by friars Bartolomé de Fuensalida and Juan de Orbita in 1618, he noted that the friars presented the Itza cacique Kan Ek' with 'the trifles that had been given them in Mérida for this purpose and also a little cacao from Tipu [...] and a very good hanger (cutlass)" (Means 1917, 69) (Figure 11.3a). Avendaño y Loyola further notes that Kan Ek' "was the first to receive, with great pleasure, a Cross which the Padres placed in his hands, and afterwards some of his men received others" (Means 1917, 73).

In his second entrada to the Itza capital in Lake Peten, Avendaño y Loyola reported that:

I gave them, as they came up to the novel sight, some necklaces and other trinkets and trifles for their wives and daughters, and for the men some knives, for the desire to possess which all came again, thus obliging me to give them presents a second time, all which I did with pleasure, one reason being the abundance of what our benefactors in their kind zeal had given me, and the other in order to draw them to our Catholic faith ... They approached me to get what I had remaining in some hampers, in which I carried for the petty King an entire suit of clothes ... and other things which I was carrying for the chiefs of Peten Ytza, in order the better to gain their good will, besides other things necessary for our ministry and support.

MEANS 1917,131

It is also apparent that Spanish priests took bells for the visita churches they had constructed in various Maya communities. Fray Diego López de Cogolludo (1688, bk. 11, Chap. 13, 645), for example, recounts that when Fuensalida's party arrived to Zaczuz, they found that the church had been burnt down and the bell thrown into the bushes. Graham $(2011,246)$ notes that when the Maya of Xibun (present day Sibun River in Belize) abandoned their community in 1630-1631, they took the "church bells and church ornaments with them." Jones $(1998,161)$ also notes that in preparation for a trip to Nojpeten in the 1690 , 

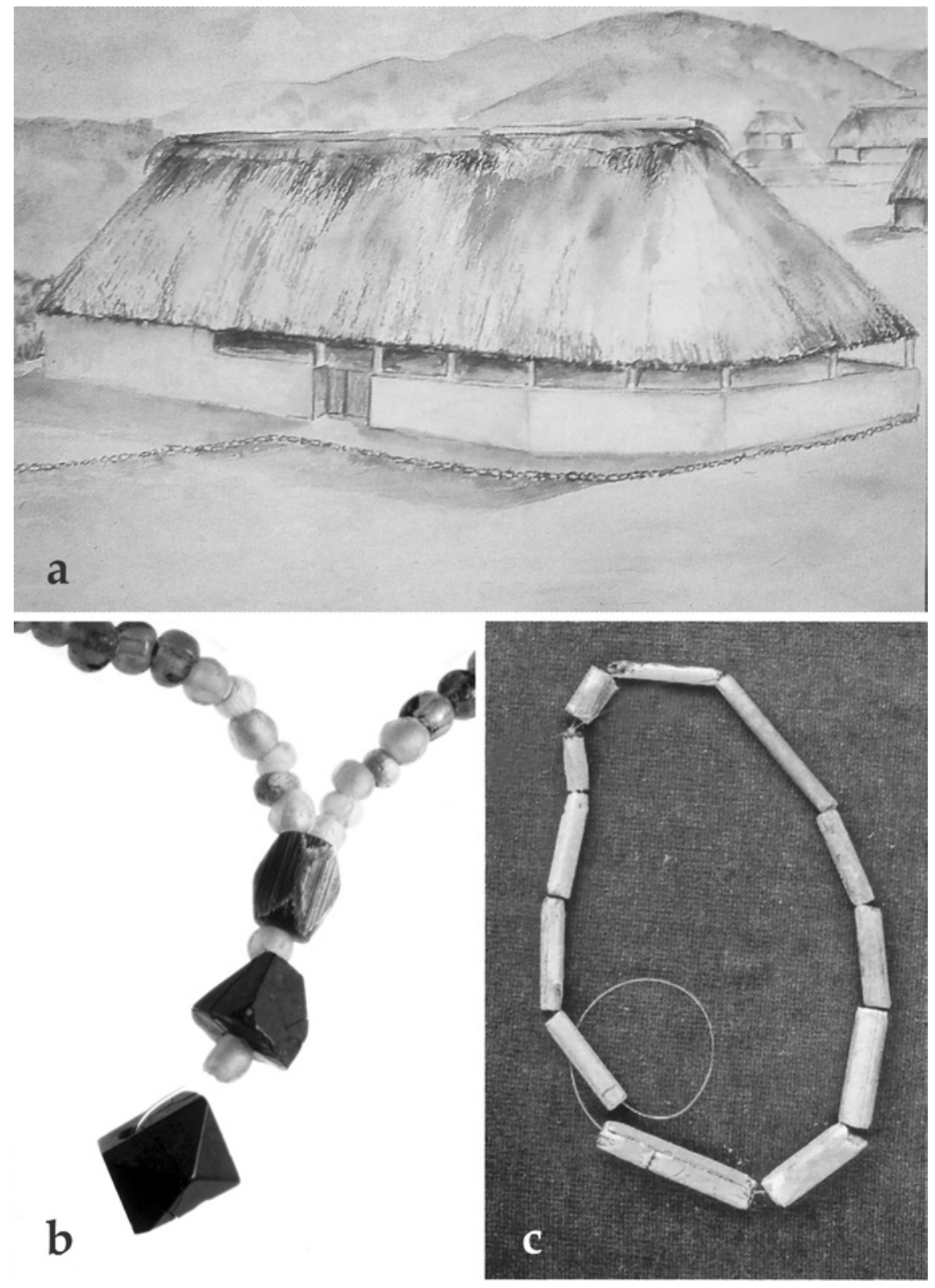

FIGURE 11.3 (a) Reconstruction of the sixteenth-century visita church at Tipu (watercolor by Louise Belanger, after Jones et al. 1986, 43); A selection of glass beads from Christian burials associated with the church at Tipu: (b) Necklace of glass beads with jet from the burial (B139) of a juvenile (5-7 years of age); (c) Nueva Cádiz glass beads from the burial of a male (18-22 years of age) (after Smith et al. 1994, Plate IVB and Figure 8) 
Fray Juan de San Buenaventura requested a list of religious paraphernalia from Fray Antonio de Silva, "the provincial of the Franciscan order in Yucatan." The list included "communion tables, chalices, chrismatories (vessels for holy oils), surplices [white vestment worn over cassock by clergy], images of saints and the pope." Fray Juan de San Buenaventura also pleaded with de Silva to send him bells for newly constructed churches in several Itza towns (Jones 1998, 161).

The Acquisition of European Goods as Payment for Services

Other references indicate that European goods were sometimes used as payment for services rendered to the Spanish by the Maya. Juan de Villagutierre y Soto-Mayor $(1983,101)$, for example, mentions that a machete was given to a "mayor" of a Maya village to help in clearing a path through the jungle in Ch'ol territory in Verapaz. This same source (Villagutierre y Soto-Mayor 1983, 312) also implies that the Maya would barter for hatchets and machetes with the Spanish. According to Jones $(1989,284)$ Ursúa y Arizmendi reported that iron tools were in high demand by the Itza Maya of the Peten Lakes region, and that Itza road builders assisting the Spaniards were "paid in machetes and axes" (Ursúa y Arizmendi 1697).

The aftermath of the massacre of Spaniards at Sacalum in 1624 provides one of the best examples of Maya acquisition of European objects by force. As Thompson $(1972,12)$ and Jones $\left(1989,185^{-187}\right)$ report, the Maya seized the weapons of some of the Spaniards while they were attending mass in Sacalum. They then slaughtered Francisco Mirones and his weaponless Spaniards in the church and took off with their arms and various other objects. When Ajk'in Pol, leader of the rebellious Maya, was captured several months later, they found in his possession the "chalices and silver from the Sacalum church, as well as a silver-plated dagger and some clothing belonging to Mirones" (Jones 1990, 188).

Similarly, Restall $(1998,74)$ notes that along the west coast of the Yucatan peninsula, renegade Maya raided communities and travelers and took their "knives, machetes, clothing, and whatever else" they carried.

During Avendaño y Loyola's second entrada to Nojpeten, he noted that in a small bay of Lake Peten 
... a nephew of the King, whom I had rewarded with some Spanish trinkets, coveting the image of a Santo Christo, which I wore on my neck, and which I had refused to give him on two occasions when he had asked me for it, on my giving a cutlass with its blade to the petty King, his uncle, seized the hand of his uncle with excessive insolence, and snatching the blade from its sheath, turned it to my breast, and passing the blade across my throat, cut the string with one blow and took the image of Christ from me.

MEANS 1917, 133.

This incident recalls another similar confrontation between Father Fuensalida and the Maya of Hubelna. In 1641, while attempting to reach Tipu from Bacalar, Fuensalida, who was accompanied by three other Franciscans and several Maya porters, found many of the towns along the way burnt and abandoned. When they arrived at Zaczuz, Fuensalida was informed that they were not welcome at Tipu. The Spanish party subsequently arranged to travel up the Yaxteel Ahau River to the newly established community at Hubelna (see Awe and Helmke 2015, 348). Following their arrival at Hubelna, Fuensalida and his party were bound, insulted, and their possessions confiscated and destroyed (López de Cogolludo 1688, bk, 11, Chap. 14, 648; Jones 1989, 53). López de Cogolludo (1688, bk. 11, Chap. 14, 647, 649) also remarked that "The one that they most mistreated and stripped bare was Lázaro [Pech], whom they knew was servant to the friars, and they took from him of a good machete that he had, lest in anger he should kill one of them" (translation by the authors).

Interestingly, Restall $(1998,74)$ has also noted that a Maya noble named Don Juan Xiu of Yaxakumche, a community near Oxkutzcab, petitioned the Spanish authorities in 1662 for permission to carry a musket. Whereas the petition in itself is noteworthy enough, it is possession of the firearm that is interesting and raises questions as to its origin and the means of its acquisition.

\section{Archaeological Evidence for Maya Consumption of European Objects}

In a 1983 publication, David Pendergast commented that "The principal defects in the evidence regarding Spanish impact on native material and nonmaterial culture in sixteenth- and seventeenth-century Belize afflict both the excavated evidence and the documentary picture" (Pendergast 1983, 113). While Pendergast's remark accurately represented the state of archaeological affairs in the late 1970s and early 1980s, a number of subsequent archaeological projects that focused on contact period sites have significantly improved 
our knowledge on the consumption of European goods by the contact period Maya. In spite of this development, some of the best archaeological information on Maya - Spanish interaction still derives from the almost two decades of research at the Belize sites of Lamanai and Tipu, both of which were investigated by Elizabeth Graham and David Pendergast along with several of their colleagues (Pendergast 1983, 1985, 1998; Graham 1987, 2011; Graham et al. 1989; Jones 1989, 1990, 1998). Other projects that have contributed to this growing record include the work of Marilyn Masson and Maxine Oland at Progresso Lagoon, Patricia McAnany's and her students research in the Sibun River Valley, Jaime Awe and Christophe Helmke's investigations in the Roaring Creek Valley of western Belize, E. Wyllys Andrews' projects in the Yucatan, INAH's explorations of cenotes in Quintana Roo, and Timothy Pugh's work in the Peten Province of Guatemala.

One of the primary research questions addressed by all these projects concerns the timing of the arrival of European objects to this part of the Maya world. Both the ethnohistoric documents and archaeological record suggest that communities in the Yucatan were among the first to acquire European goods, and that this process started with the expedition of Francisco Hernández de Córdoba in 1517 (Díaz del Castillo 1956). For sites in Belize where Spanishmade objects have been discovered, Pendergast and his colleagues argue that archaeological investigations "permit fairly precise fixing of the time of use of the community within the span of the sixteenth and seventeenth centuries" (Pendergast et al. 1993, 70). This is particularly "true of olive jar and majolica types, which at Lamanai and very probably also at Tipu cannot be later than the 1630 and are most likely to have reached the sites between 1544 and 160o" (Pendergast et al. 1993, 70). These dates are corroborated by John Goggin's (1960, 20-24, 1968, 101-114) analysis of olive jars and majolica which he suggests were being imported into the area from ca. 1580 to $185^{\circ}$ (see also James 1988).

For the Peten, the initial introduction of European objects takes place during the 1524-1525 entrada of Cortés into this area of the Maya lowlands (Blacker and Rosen 1962). Recall that during his brief stay at Nojpeten, Cortés gifted several objects to Kan Ek', and left his horse in the care of the cacique (Bennett 1998, 189-190). Subsequently, and particularly during the years preceding the 1697 conquest of the Itza Maya, an array of Spanish goods, including clothing, glass beads, machetes and a variety of other objects were gifted to the Itza to encourage their conversion to Catholicism and their capitulation to Spanish control (Jones 1998; Means 1917, 131; Pugh et al. 2012, 6; Villagutierre y SotoMayor 1983).

Another question that archaeologists have tried to address concerns the purpose(s) for which the Maya employed the various exotic goods acquired from the Spanish. Pendergast $(1983,113)$ previously noted that the ethnohistoric 
literature is quite vague to this end, and "are never descriptive of Maya or European goods as they were understood or utilized within the native cultural context." Indeed, the ethnohistoric sources mostly inform us about the reasons why the Spanish provided their European goods to the Maya, and we now know that these efforts were primarily to establish or promote acquiescence or good relationships. Fortunately, the recently improved archaeological record is now allowing us to fill this void, and our study of the contextual distribution of European objects at contact period sites suggests that the Maya utilized Spanish objects for three main purposes. These include a) functional/ mundane reasons, b) as status markers, and c), for ritual purposes.

\section{Functional Uses of European Goods by the Maya}

David Pendergast (1983, 116; also Graham et al. 1989) observed that the intrusion of Spaniards into the Maya area appears to have affected pre-Hispanic trade in obsidian. Given the predominantly utilitarian function of this commodity, its absence from local markets would certainly have driven the lowland Maya to seek out and acquire axes and machetes from the Spanish. The ethnohistoric literature unquestionably reflects this increasing demand for metal tools and is rife with passages describing the constant efforts of the Maya to acquire them. We have, for example, already referred to the Maya who, when taken captive by Díaz de Velasco's party along the shores of Lake Peten, informed the Spaniards that he was looking "for merchants to buy axes and machetes" (Jones 1998, 138). Recall too that during that same expedition, Velasco's Mopan guides asked a group of Itza warriors to "be peaceable and not fight, because those were merchants who sold axes and machetes" (Jones 1998, 135). In Fray Juan de San Buenaventura's letter to the provincial Silva, he wrote: "They also say that for the past six months the Itzas who came to look for iron tools among these Cehaches told them not to run away from the Spaniards when they came" (Jones 1998, 159). Jones $(1998,205)$ adds that "Trade for metal tools," particularly axes and machetes, was the primary motivator "for increasing contact with the Spaniards." Avendaño y Loyola also reported that on his last day in Nojpeten, several leaders confronted Kan Ek' deriding him for his friendship with the Spanish, and questioned whether the reason for his cozy relationship with the foreigners was to acquire "axes and machetes for their cultivations" or "the goods and clothing of Castile" (Jones 1998, 209).

Metal tools have been found at several sites in Belize and in the Peten. At Tipu, for example, Graham (1998) as well as Graham et al. (1989, 1256; 1985, 207-210) note that "metal hooks, iron nails, locks, and other Spanish ironwork 
occur in refuse deposits and building debris." Graham (2011, 365, n. 184) also recovered metal needles in middens at Tipu. At Lamanai, Pendergast (1983, 129, Figs. 7-8) found several iron artifacts in Str. N11-18, including a possible knife handle, two knife blades, what may be a horseshoe and an axe. The contexts of discovery of these objects strongly suggest that their primary function served practical mundane purposes.

For the Lacandon area of Chiapas and Peten, Joel Palka (2005) reports that throughout the colonial period, and into the early twentieth century, the people of this region acquired a variety of European objects that were used for various purposes. Among these European goods were white earthenware ceramics, glass bottles, metal cooking pots, machetes, axes and files. Here again, the very nature of the latter four objects leave little doubt that their primary function was utilitarian.

In a recent analysis of skeletal remains from a burial site in the Mensabak area of the Lacandon forests in Chiapas, Cucina et al. (2015) concluded that the remains displayed evidence of violent deaths and wounds caused by metal weapons such as machetes and swords. Maxine Oland and Palka $(2016,480)$ note that the Mensabak region was an unconquered zone and that this type of violence was a result of the use of acquired metal tools in "local indigenous conflicts." The Lacandon Maya of Chiapas continued to obtain European goods, particularly metal tools and majolica well into the twentieth century (Palka 2005).

Nancy Farris $(1984,121)$ notes that "Steel axes and other Spanish tools [...] were introduced via a clandestine trade with the conquered areas to the north" and that these were likely "substituted for the manufactured goods formerly imported from highland Mexico." She (Farris 1984, 70) also notes that the Maya acquired steel machetes from the Spanish for everyday use, and that "despite official prohibitions" the colonial Maya were able to acquire guns and gunpowder for hunting (Farris 1984, 70).

Following his excavations of Str. N11-18 at Lamanai, Pendergast concluded that the concentration of iron objects in the building "underscores the importance of the structure and its occupants, not as regards European impact on local technology but rather in terms of use of imported objects as physical manifestations of rank or status that derived from Spanish interest" (Pendergast 1983, 130) (Figure 11.4a). In addition to metal objects, $91 \%$ of all glass beads found at Lamanai were recovered "within and around Str. N11-18" which 

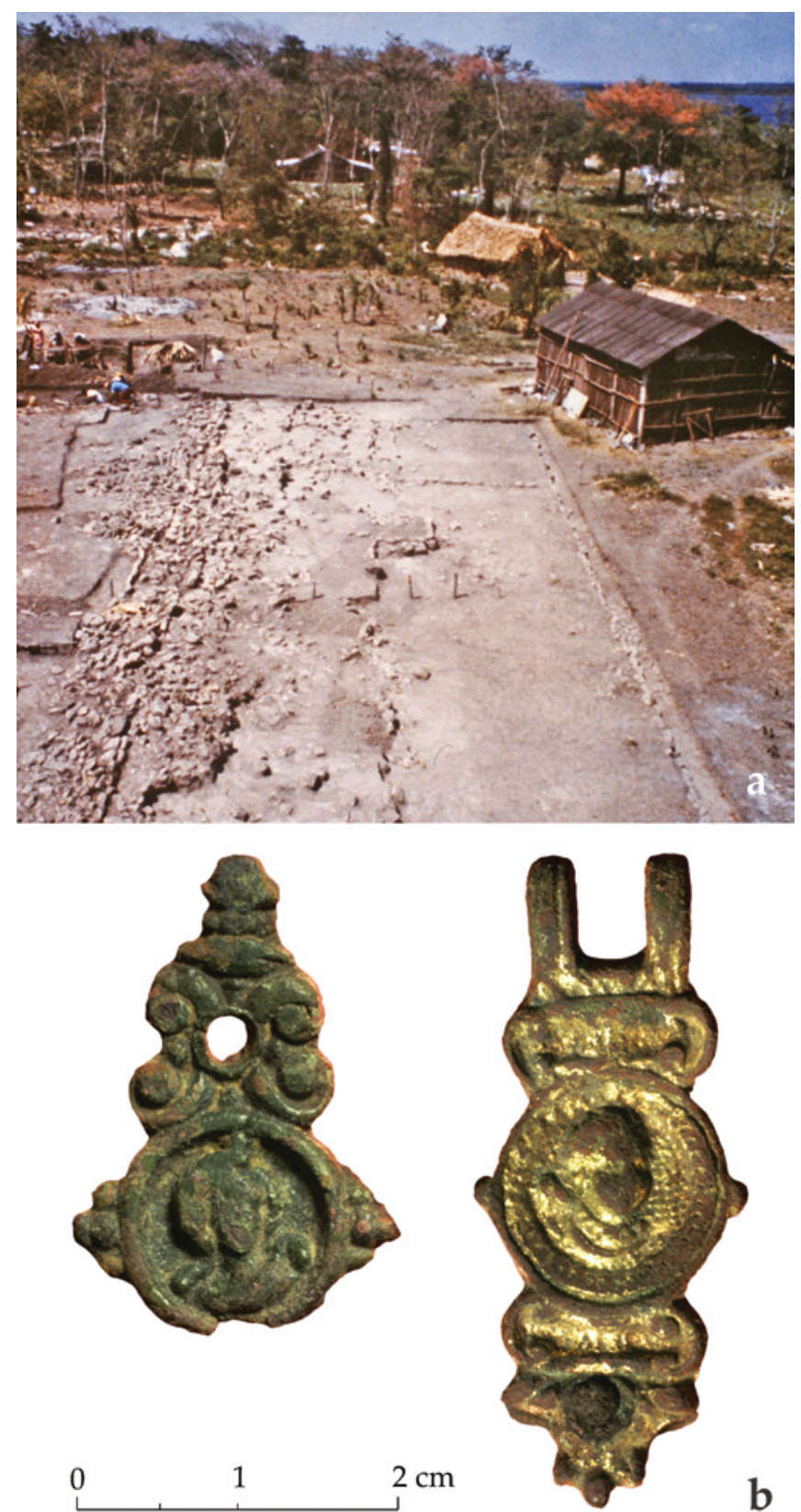

FIGURE 11.4 (a) Structure N11-18 at Lamanai, where many European objects have been found, is the probable residence of the site's cacique (after Pendergast 1983, Figure 2); (b) Gilded brass book hinges decorated with figurative medallions, discovered within Str. N11-18. Based on the style of these pieces these date to no later than ca. AD $155^{\circ}$ PHOTOS COURTESY OF DAVID PENDERGAST 
Pendergast $(1983,128)$ identified as the primary residence of the cacique. Other materials recovered from the cacique's house included leaves from two brass book hinges (Pendergast 1983, 129) (Figure 11.4b). This clear concentration of European goods around Str. N11-18, vis-a-vis other residences at the site, provides compelling evidence that these exotics represented important status objects.

The archaeological context of European objects at Tipu differs from that at Lamanai. At the former, most Spanish imports were found in association with burials (Graham 1991, 2011; Graham et al. 1985, 1989; Pendergast 1983). For example, approximately 720 glass beads were recovered at Tipu, the majority of which were associated with nine child burials (Smith et al. 1994, Table 1). The other beads were found in association with three male and three female adults, leading Pendergast $(1983,128)$ to contend that the presence of these adults "among the bead-associated burials also suggests the use of beads as markers of rank or status." Excavations of a large house designated as Str. H12-7, at Tipu, also yielded "olive jar sherds, a copper ring, a glass bead, and a lock plate for a chest” (Graham 2011, 230).

At both Lamanai and Tipu, Pendergast $(1983,125)$, and Graham (1991, 323) recovered fragments of majolica bowls and dishes. At both sites, however, the frequency of these glazed Spanish wares was low, suggesting that the importation of European pottery was not very significant at either of these communities. The low frequency of majolica at other sites, seems to confirm this observation. This is undoubtedly partly caused by the continued and relatively expedient manufacture of ceramics from local clays as well as the difficulty of transporting European glazed wares over large distances of uneven terrain. Despite their low frequencies, however, the contextual distribution of majolica seems to be highest in buildings associated with individuals of higher status. This is certainly the case in the Sibun River Valley where Steve Morandi $(2003,151-152 ; 2010)$ found numerous fragments of Spanish majolica, a small copper star, and olive jar fragments in an elite residence at the Spanish colonial settlement of Cedar Bank.

At Progresso Lagoon in northern Belize, investigations by Oland and Masson (2005) recovered several artifacts of Spanish origin. With the exception of olive jar fragments, most of the European goods included "luxury items" such as glass beads, a glass earring, and majolica plates. Here again, all goods of European manufacture were discovered in Structure 1, a large and impressive building that Oland $(2012,188-189)$ associated with elite residence. The fact that this large residence "had more exotic consumption and craft production than any other house" at the site is a pattern that mirrors the distribution of exotics at Lamanai (Oland 2012, 188-189). 
To the west, in Guatemala, Pugh $(2009,382)$ noted that "No evidence at Zacpeten documents that European goods "trickled down" to non-elites at the site; the goods appear to have been restricted to public ceremony and elite power play." In Str. T29 at San Bernabé on the Tayasal peninsula, Pugh et al. $(2012,15)$ discovered "10 majolica sherds, four pieces of glass, a mirror fragment, lead shot, a square nail, four pieces of unidentified iron, a copper alloy ring, and a silver coin." They (Pugh et al. 2012, 15) also concluded that Str. T29 was likely "a residence of the San Bernabé parish."

Interestingly, Pugh et al. (2012, 15-16) suggest that most of the Spanish-style objects found at Tayasal were likely produced in the Americas. This includes the coin whose weight, which does not confirm to royal decree, suggests that it was minted in Santiago de Guatemala sometime during the early colonial period. They (Pugh et al. 2012, 17) further suggest that because most of these objects were found in middens, it is possible "that the value of exotic goods changed over the contact and colonial periods as they became more common." We must consider, however, that these middens were adjacent to some of the largest platforms in the community, thus were likely associated with higher status residences.

Another example of the association of European objects with elite Maya residences comes from our own work in the Roaring Creek Valley of western Belize. At a site, which could possibly be the location of the contact period community known as Hubelna (see Awe and Helmke 2015, 345-346, Figure 1), one of our workers discovered several gray-glazed olive jar sherds. The plazuela group where the sherds were found are among the largest mounds at the site, thus likely representing the residence of elite members of this contact period community. At the Cedar Bank site along the Sibun River, McAnany and her colleagues $(2004,306)$ also discovered several olive jar fragments in association with a large contact period platform. Here again, McAnany et al. (2004) and Morandi (2010; also Jones 1989, 200) note that Cedar Bank may have been the location of a Spanish visita church that was constructed at the end of the sixteenth century.

Colonial documents provide equally compelling evidence that European objects often represented important status markers in contact period Maya society. The ethnohistoric sources, for example, mention several cases where Castilian clothing and sheathed knives were gifted to Maya leaders. This is particularly true in the case of the aforementioned Kan Ek', cacique of the Itza. We already noted above that Cortés gifted Kan Ek' some Spanish clothes on his brief stop at Nojpeten in 1524-1525. During Avendaño y Loyola's preparation for his trip to Nojpeten, Ursúa, then Governor of Yucatan, also gave him a "suit of Spanish clothing for Kan Ek', complete with a hat and staff of office. The intention was to dress the Itza ruler up as a typical Yucatan Maya alcalde [...] 
and a means of co-optation. Other gifts [...] included a machete and sheath, a knife with a belt, and three yards of taffeta" plus "numerous smaller gifts, such as necklaces and knives, intended as general handouts” (Jones 1998, 188).

\section{$9 \quad$ European Goods Used for Ritual Purposes}

Pugh (2009) argues that although several scholars have suggested that the primary factor which drove the Maya to desire and acquire European objects was the technological "superiority" of these goods, the location of these objects in excavated Maya communities indicate that they "often employed these tools for "non-utilitarian" - particularly ceremonial - purposes" (Pugh 2009; also see Miller and Hamell 1986, 314).

At Zacpeten, which was occupied by the Kowoj Maya until about 1650, Pugh (2009; also see Oland and Palka 2016, 482, Figure 4) recovered several colonial period artifacts of Spanish origin. Among the latter was the modified jawbone of a cow, iron tools, a white clay ball and a lead musket ball, along with Maya objects that were recovered in public and elite residential architecture (Figure 11.5). Pugh (2009, 382) argues that the Maya incorporated these exotic Spanish

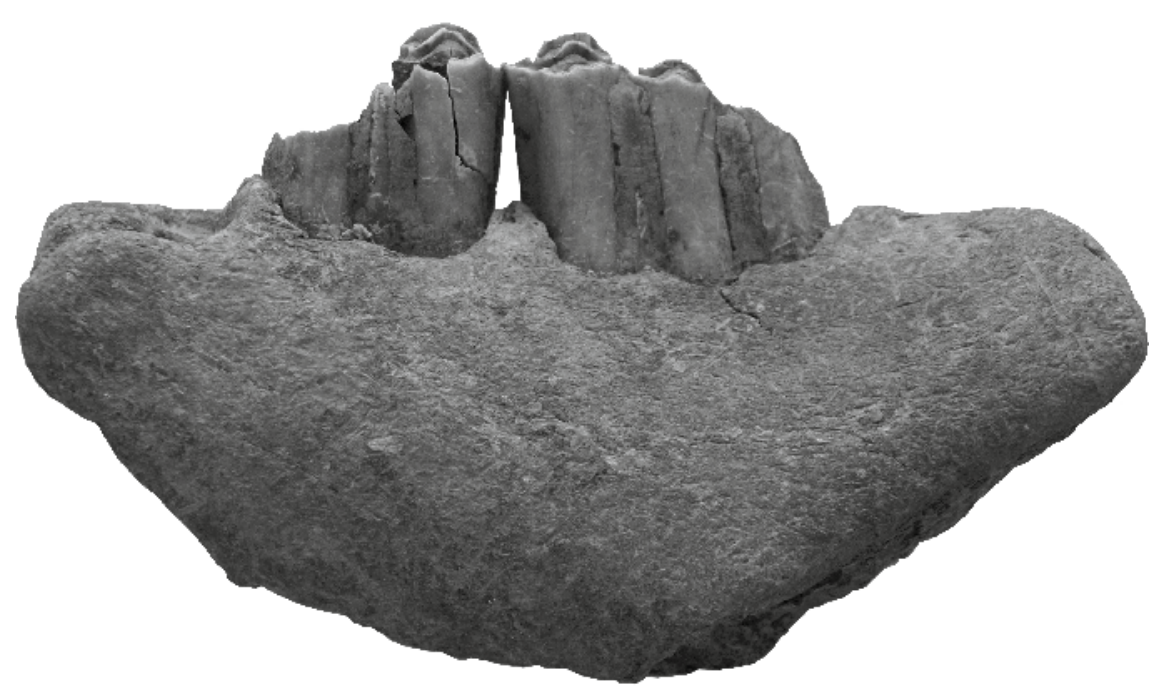

0 $5 \mathrm{~cm}$

FIGURE 11.5 Partial cow mandible found in deposits dated to ca. AD 1650 at Zacpeten PHOTO BY PRUDENCE RICE, COURTESY OF TIMOTHY PUGH 
objects in caches and offerings to consecrate "the sacred spaces at Zacpeten," and to "harness the power of the Europeans" (Oland and Palka 2014, 481). According to Pugh $(2009,111)$ "The Kowoj appropriated the peripheral materials and planted them in their most central ceremonial spaces as positive contagion."

Pugh $(2009,382)$ also comments on the interesting Kowoj practice of incorporating European fauna, in this case cow remains, in cache deposits at Zacpeten. Interestingly, a similar pattern has been found at Cozumel where the remains of cattle, horses and sheep were recovered in ritual contexts (Hamblin 1984, 142-143). Yet another example of this practice at Cozumel is reflected by the discovery of contact period ceramic vessels along with olive jars, fragments of majolica and cow bones that were ritually deposited into local cenotes. The latter were recovered by an underwater archaeology project co-directed by Luis Alberto Martos López $(2008,107)$.

Investigations by the authors (Awe and Helmke 2015) indicate that the ritual deposition of olive jars was a relatively common practice during and after the Spanish conquest of the Maya lowlands. For example, we previously reported on a complete olive jar that was cached and ritually killed in a cave in the Roaring Creek Valley of western Belize (Awe and Helmke 2015) (Figure 11.6a). Other complete and fragmentary remains of olive jars, also from sacred cave contexts, are known from Xcaret, Quintana Roo (Andrews and Andrews 1975, 72, figure 88), the Crocodile Cenote system in Cozumel (Martos López 2008, 107), from the Cenote Canun near the sites of Acanceh and Mayapan in Yucatan (Anthony Andrews, personal communication 2010), and from the cenote Xbatun (CONACULTA 2008; González et al. 2004; Alfredo Barrera Rubio, personal communication 2010). It is important to note that one of the Xbatun olive jars also displays a small kill hole on its side similar to that on one of the Roaring Creek specimens. In addition to the above, Oland $(2014,2017)$ also recovered an olive jar fragment cached beneath an altar in a shrine next to the "primary elite residence" at Progresso Lagoon in northern Belize.

Investigations in Belize provide various other examples of the deposition of exotic Spanish objects in ritual cave contexts. In the Roaring Creek Valley, for example, we (Awe and Helmke 2015) previously reported on the discovery of a European rapier sword that was cached in a small cave that is located in proximity to Olive Jar Cave (Figure 11.6b). East of Roaring Creek, Peterson (2006, 26) investigated several cave sites in the Gracy Rock area of the Sibun River drainage that contained both Spanish and British colonial remains, including olive jar fragments. One of the sites, Hickatee Cave, reported by Peterson $(2006,90)$ contained several European artifacts, including majolica. Another particularly interesting find is the discovery of historic-period graffiti written on flowstone 

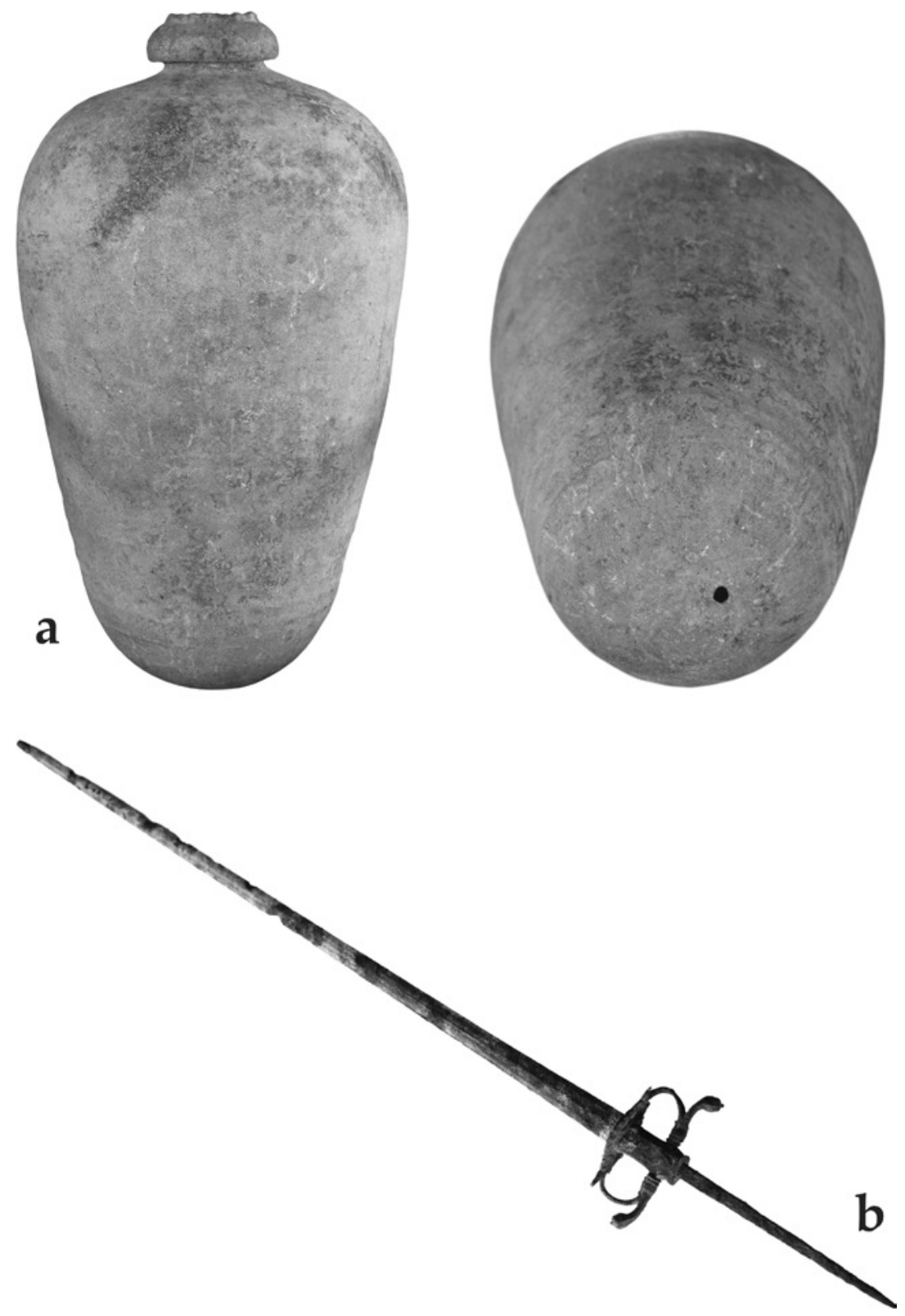

FIGURE 11.6 (a) Two views of a Spanish olive jar dated to ca. AD 1540-1630, ritually killed and deposited within a cave in the Roaring Creek Valley of western Belize. The jar is $48 \mathrm{~cm}$ tall (after Awe and Helmke 2015, Figure 2); (b) European rapier sword that was cached in a small cave located in the Roaring Creek Valley of western Belize. Total length is $87.8 \mathrm{~cm}$

PHOTO BY JAIME AWE AND CHRISTOPHE HELMKE 
within Actun Chanona. The text of the graffiti includes the Spanish Word "Dios" (Peterson 2006, 36). In all these cases, we believe that the Maya purposely deposited these European objects in sacred cave contexts as part of a long established set of cave rituals (Helmke 2009; Prufer and Brady 2005), but here replacing indigenous objects with European material culture, because the exotic nature of the foreign objects may have increased their "ritual value."

A major aim of this chapter was to demonstrate that both the ethnohistoric literature and the archaeological record contain substantial information on the acquisition of European-made objects by the contact period Maya. Based on this brief review, we would argue that both these sources of information certainly confirm this position. Furthermore, these highly complementary data indicate that although the peripheral locations of most sixteenth- and seventeenth-century Maya communities in Belize and the Peten placed them outside of, and away from, the major centers of early colonial Spanish control, the frontier Maya of Belize and the Peten were still able to acquire Spanish goods. The historic documents, in fact, suggest that the Spanish keenly gifted and traded items to prompt acquiescence and peaceable relations. At the same time, the local vantage reveals that these frontier Maya regularly sought out these exotic objects, and they actively and purposely expended efforts to acquire them. This is perhaps best illustrated by Avendaño y Loyola's comment that the Maya demonstrated an "insatiable desire" for European goods (Means $1917,131)$.

The ethnohistoric record also informs us that the Maya acquired European objects by way of five main methods. These included direct gifts from the Spanish, through trade or barter, and sometimes as payment for services rendered to the Spanish. In other cases, the Spanish provided European goods to the Maya as rewards for accepting conversion to Christianity. Occasionally, however, the Maya also obtained these goods by forceful means, particularly during skirmishes as well as periodic revolts and uprisings against the Spaniards.

Our research further indicates that the impetus that fueled the Maya desire for European goods was for their use as status objects, for practical mundane purposes and for their use as special offerings in ritual contexts. Both the ethnohistoric and archaeological record indicate that European objects may have actually replaced native exotics as key indicators of rank and status. As Oland $(2017,129)$ has noted: "When exotic objects were used in processes of defining 
and identifying indigenous rank, European objects were often easily adapted to elite purposes." Indeed, Maya lives were transformed with the introduction of Europeans into their world. One aspect of Maya life that was definitely impacted, and which Pendergast $(1983,116)$ previously noted, was the trade in exotics that derived from other areas of Mesoamerica. In many cases, European goods replaced these native objects and possession of the foreign objects quickly became one of the standards for measuring and displaying rank and status. For this reason, the distribution of some Spanish objects was likely guarded and controlled by the Maya elite. Pugh (2009, 382), for example, has argued that "No evidence at Zacpeten documents that European goods "trickled down" to non-elites at the site; the goods appear to have been restricted to public ceremony and elite power play." The contextual distribution of European objects at the archaeological sites of Lamanai, Tipu, Cedar Bank and Progresso Lagoon in Belize, and at Zacpeten and Tayasal in the Peten supports this position and provides compelling evidence for the predominantly elite consumption of these exotic objects.

The introduction of European objects into the native value system, also made them worthy of inclusion in ritual and religious contexts. The caching of the European sword in Rapier Cave, and the numerous olive jars that have been found in caves across Belize and the Yucatan are ample testimony of the increasing inclusion of European exotica in sacred Maya contexts. This change in the caching tradition of the contact period Maya is also evident at surface sites and is clearly reflected by the placement of olive jar fragments beneath an altar at Progresso Lagoon, by the European grave goods found in the burials at Lamanai and Tipu, as well as by the various Spanish objects that were used to consecrate "the central axes of sacred spaces" at Zacpeten (Pugh 2009, 382). Beside the special value that their exotic nature imbued them with, the Maya likely incorporated European objects in their sacred contexts to harness the power they represented and to revitalize "themselves and their world through the contagion of alterity" (Pugh 2009, 383). What is also intriguing to consider in this regard, is how the idea of exoticism, or the attractiveness of these foreign material goods, was maintained throughout the period of contact and how it was fostered or altered in later times.

In spite of the apparent elite control over some European objects, and their ritualized incorporation in caches, burials and sacred locations, it is also evident that the Maya utilized several European goods for basic mundane and utilitarian purposes. This is particularly true of axes and machetes that provided the Maya with more hardy and efficient tools for preparing their kitchen gardens, fields or milpa. In later years, the colonial Maya were also able to acquire guns and gunpowder for hunting (Farris 1984, 70). The subsequent use of 
axes, machetes and guns for violent confrontations, however, unquestionably affected the lives of the lowland Maya more than we can ever measure, and they continue to impact the world of the Maya into the twenty-first century.

\section{Acknowledgments}

Many kind and heartfelt thanks to Elizabeth Graham, Grant Jones, David Pendergast, Mathew Restall, Maxine Oland and Timothy Pugh for insightful comments and productive conversations on European-Maya interactions over the years. We are particularly grateful to Floris Keehnen and Corinne Hofman for inviting us to contribute this chapter to the volume. We also extend our thanks to Elizabeth Graham, David Pendergast, Prudence Rice and Timothy Pugh for permission to include illustrative materials that have greatly enriched this chapter. All shortcomings remain the responsibility of the authors.

\section{References}

Andrews IV, E. Wyllys and Anthony P. Andrews. 1975. A Preliminary Study of the Ruins of Xcaret, Quintana Roo, Mexico - With Notes on Other Archaeological Remains on the East Coast of the Yucatan Peninsula. Middle American Research Institute Publication 40. New Orleans: Tulane University.

Avendaño y Loyala, Fray Andrés de. 1987. Relation of Two Trips to Peten: Made for the Conversion of the Heathen Ytzaex and Cehaches, edited by Frank E. Comparato; translated by Charles P. Bowditch and Guillermo Rivera. Culver City: Labyrinthos.

Awe, Jaime J. and Christophe Helmke. 2015. "The Sword and the Olive Jar: Material Evidence of Seventeenth-Century Maya - European Interaction in Central Belize." Ethnohistory 62 (2): 333-360.

Bedini, Silvio A. 1992. The Christopher Columbus Encyclopedia, Volume I. New York: Simon and Schuster.

Bennett, Deb. 1998. Conquerors: The Roots of New World Horsemanship. Solvang: Amigo Publications.

Blacker, Irwin R. and Harry M. Rosen. 1962. Conquest: Dispatches of Cortez from the New World. New York: The Universal Library, Grosset and Dunlap.

Chamberlain, Robert S. 1948. The Conquest and Colonization of the Yucatan 1517-1550. Washington, D.C.: Carnegie Institution of Washington.

Chase, Arlen F. and Prudence Rice. 1985. "Postclassic Temporal and Spatial Frames for the Lowland Maya: A Background." In The Lowland Maya Postclassic, edited by Arlen F. Chase and Prudence M. Rice, 9-22. Austin: University of Texas Press. 
Clendinnen, Inga. 1987. Ambivalent Conquest: Maya and Spaniard in the Yucatan 1517-1570. New York: Cambridge University Press.

Columbus, Ferdinand. 1960. The Life of the Admiral Christopher Columbus by his son Ferdinand. Translated and annotated by Benjamin Keen. London: Folio Society.

CONACULTA (Consejo Nacional para la Cultura y las Artes). 2008. Cuevas y cenotes mayas. Temporary exhibition, October 2008 - February 2009. Mexico, D.F.: Museo del Templo Mayor.

Cucina, Andrea, Vera Tiesler, and Joel Palka. 2015. "The identity and worship of human remains in rockshelter shrines among the northern Lacandons of Mensabak." Estudios de Cultura Maya 45:141-169.

Díaz del Castillo, Bernal. 1956. The Bernal Diaz Chronicles: The True Story of the Conquest of Mexico. Translated by Albert Idell. Garden City: Doubleday \& Co., Inc.

Díaz del Castillo, Bernal. 1962. The Conquest of New Spain. Translated by J.M. Cohen. Middlesex: Penguin Books.

Farris, Nancy M. 1984. Maya Society under Colonial Rule: The Collective Enterprise of Survival. Princeton: Princeton University Press.

Goggin, John M. 196o. The Spanish Olive Jar: An Introductory Study. Publications in Anthropology No. 62. New Haven: Yale University.

Goggin, John M. 1968. Spanish Majolica in the New World. Publications in Anthropology No. 72. New Haven: Yale University.

González, Arturo González, Carmen Rojas Sandoval, and Octavio del Río Lara. 2004. Atlas Arqueológico Subacuático para el registro, estudio y protección de los cenotes en la península de Yucatán. Mexico: Instituto Nacional de Antropología e Historia, Subdirección de Arqueología Subacuática.

Graham, Elizabeth. 1987. "Terminal Classic to Early Historic-Period Vessel Forms from Belize." In Maya Ceramics: Papers from the 1985 Maya Ceramic Conference, Part 1, edited by Prudence M. Rice and Robert J. Sharer, 73-98. Oxford: British Archaeological Reports, International Series 345(i).

Graham, Elizabeth. 1991. "Archaeological Insights into Colonial Period Maya Life at Tipu, Belize." In Columbian Consequences, Vol. 3: The Spanish Borderlands in PanAmerican Perspective, edited by David Hurst Thomas, 319-335. Washington, D.C.: Smithsonian Institution Press.

Graham, Elizabeth. 1998. "Mission Archaeology." Annual Review of Anthropology 27: 25-62.

Graham, Elizabeth. 2011. Maya Christians and Their Churches in Sixteenth-Century Belize. Gainesville: University Press of Florida.

Graham, Elizabeth A., Grant D. Jones, and Robert R. Kautz. 1985. "Archaeology and Ethnohistory on a Spanish Colonial Frontier: An Interim Report on the MacalTipu Project in Western Belize." In The Lowland Maya Postclassic, edited by Arlen F. Chase and Prudence M. Rice, 206-214. Austin: University of Texas Press. 
Graham, Elizabeth, David M. Pendergast, and Grant D. Jones. 1989. "On the Fringes of Conquest: Maya-Spanish Contact in Colonial Belize." Science 246: 1254-1259.

Hamblin, Nancy L. 1984. Animal Use by the Cozumel Maya. Tucson: University of Arizona Press.

Hammond, Norman. 1988. Ancient Maya Civilization. Third edition. Cambridge: Cambridge University Press and Rutgers University Press.

Helmke, Christophe G.B. 20og. "Ancient Maya Cave Usage as Attested in the Glyphic Corpus of the Maya Lowlands and the Caves of the Roaring Creek Valley, Belize." PhD diss., Institute of Archaeology, University of London.

James, Stephen R., Jr. 1988. "A Reassessment of the Chronological and Typological Framework of the Spanish Olive Jar." Historical Archaeology 22 (1): 43-66.

Jones, Grant D. 1989. Maya Resistance to Spanish Rule: Time and History on a Spanish Frontier. Albuquerque: University of New Mexico Press.

Jones, Grant D. 1990. "Prophets and Idol Speculators: Forces of History in the Lowland Maya Rebellion of 1638." In Vision and Revision in Maya Studies, edited Flora S. Clancy and Peter D. Harrison, 179-192. Albuquerque: University of New Mexico Press.

Jones, Grant D. 1998. The Conquest of the Last Maya Kingdom. Stanford: Stanford University Press.

Jones, Grant D., Robert R. Kautz, and Elizabeth A. Graham. 1986. "Tipu: A Maya Town on the Spanish Colonial Frontier." Archaeology 39 (1): 40-47.

Keegan, William H. 1992. The People Who Discovered Columbus: The Prehistory of the Bahamas. Gainesville: University Press of Florida.

Keehnen, Floris W.M. 2012. "Trinkets (f)or Treasure? The role of European Material Culture in Intercultural Contacts in Hispaniola during Early Colonial Times." Master thesis, Faculty of Archaeology, Leiden University.

Keen, Benjamin. 1959. The Life of the Admiral Christopher Columbus by his Son Ferdinand. New Brunswick: Rutgers University Press.

López de Cogolludo, Diego. 1688. Historia de Yucathan. Madrid: Juan García Infanzón.

Martos López, Luis Alberto. 2008. "Underwater Archaeological Exploration of the Maya Cenotes." Museum International 6o (4): 100-110.

McAnany, Patricia A., Eleanor Harrison, Polly A. Peterson, Steven Morandi, Satoru Murata, Ben S. Thomas, Sandra L. López Varela, Daniel Finamore, and David G. Buck. 2004. "The Deep History of the Sibun Valley." Research Reports in Belizean Archaeology 1: 295-310.

Means, Philip Ainsworth. 1917. History of the Spanish Conquest of Yucatanand of the Itzas. Papers of the Peabody Museum of Archaeology and Ethnology Vol. 7. Cambridge: Harvard University.

Miller, Christopher L. and George R. Hamell. 1986. “A New Perspective on Indian-White Contact: Cultural Symbols and Colonial Trade." Journal of American History 73 (2): $311-328$. 
Morandi, Steven J. 2003. "Colonial-Period Occupational Debris at Cedar Bank (Operation 40)." In Between the Gorge and the Estuary: Archaeological Investigations of the 2001 Season of the Xibun Archaeological Research Project, edited by Patricia A. McAnany and Ben S. Thomas, 153-158. Boston: Department of Archaeology, Boston University.

Morandi, Steven J. 2010. "Xibun Maya: The Archaeology of an Early Spanish Colonial Frontier in Southeastern Yucatan." PhD diss., Boston University.

Oland, Maxine H. 2012. "Lost among the Colonial Maya: Engaging Indigenous Maya History at Progresso Lagoon, Belize." In Decolonizing Indigenous Histories: Exploring Prehistoric/Colonial Transitions in Archaeology, edited by Maxine Oland, Siobhan M. Hart, and Liam Frink, 178-200. Tucson: University of Arizona Press.

Oland, Maxine H. 2014. "With the Gifts and Good Treatment That He Gave Them': Elite Maya Adoption of Spanish Material Culture at Progresso Lagoon, Belize." International Journal of Historical Archaeology 18: 643-667.

Oland, Maxine H. 2017. "The Olive Jar in the Shrine: Situating Spanish Objects within a 15th-to-17th Century Maya Worldview." In Foreign Objects: Rethinking Indigenous Consumption in American Archaeology, edited by Craig N. Cipolla, 127-142. Tucson: University of Arizona Press.

Oland, Maxine and Joel W. Palka. 2016. "The Perduring Maya: New Archaeology on Early Colonial Transitions." Antiquity 90: 472-486.

Oland, Maxine H. and Marilyn A. Masson. 2005. "Late Postclassic-Colonial Period Maya Settlement on the West Shore of Progresso Lagoon." Research Reports in Belizean Archaeology 2: 223-230

Palka, Joel. 2005. Unconquered Lacandon Maya: Ethnohistory and Archaeology of Indigenous Culture Change. Gainesville: University Press of Florida.

Pendergast, David M. 1983. "Worlds in Collision: The Maya/Spanish Encounter in Sixteenth and Seventeenth Century Belize." Proceedings of the British Academy 81: $105^{-143 .}$

Pendergast, David M. 1985. "Lamanai, Belize: An Updated View." In The Lowland Maya Postclassic, edited by Arlen F. Chase and Prudence M. Rice, 91-103. Austin: University of Texas Press.

Pendergast, David M. 1998. "Intercessions with the Gods: Caches and Their Significance at Altun Ha and Lamanai, Belize." In The Sowing and the Dawning: Termination, Dedication and Transformation in the Archaeological and Ethnographic Record of Mesoamerica, edited by Shirley Boteler Mock, 55-64. Albuquerque: University of New Mexico Press.

Pendergast, David M., Grant D. Jones, and Elizabeth Graham. 1993. "Locating Maya Lowlands Spanish Colonial Towns: A Case Study from Belize." Latin American Antiquity $4(1): 59-73$.

Peterson, Polly. 2006. "Ancient MayaRitual Cave Use in the Sibun Valley, Belize." PhD diss., Boston University. 
Prufer, Keith M. and James E. Brady (eds). 2005. Stone Houses and Earth Lords: Maya Religion in the Cave Context. Boulder: University Press of Colorado.

Pugh, Timothy W. 2009. "Contagion and Alterity: Kowoj Maya Appropriations of European Objects.” American Anthropologist 111: 373-386.

Pugh, Timothy W., José Romulo Sanchez, and Yuko Shiratori. 2012. "Contact and Missionization at Tayasal, Peten, Guatemala." Journal of Field Archaeology 37 (1): 3-19.

Restall, Matthew. 1998. Maya Conquistador. Boston: Beacon Press.

Scholes, France V. and Ralph L. Roys. 1948. The MayaChontal Indians of Acalan-Tixchel: A Contribution to the History and Ethnography of the YucatanPeninsula. Carnegie Institution of Washington, Publication 560 . Washington, D.C.: Carnegie Institution of Washington.

Smith, Marvin, Elizabeth Graham and David M. Pendergast. 1994. "European Beads from Spanish-Colonial Lamanai and Tipu, Belize." Journal of the Society of Bead Researchers 6: 21-47.

Thompson, J. Eric S. 1972. The Maya of Belize: Historical Chapters since Columbus. Belize: Benex Press.

Ursúa y Arizmendi, Martín de. 1697. Testimonia de Martín de Ursúa y Arizmendi. Seville: Archivo General de Indias, Guatemala 151.

Van Oss, Anna. 1986. Catholic Colonialism: A Parish History of Guatemala, 1524-1821. Cambridge: Cambridge University Press.

Villagutierre y Soto-Mayor, Juan de. 1983. History of the Conquest of the Province of the Itza. Translated by Robert D. Wood; edited by Frank E. Camparato. Culver City: Labyrinthos. 